\title{
PENGEMBANGAN PENDEKATAN KREATIF INOVATIF UNTUK MENINGKATAN JIWA KEWIRAUSAHAAN
}

\author{
Selly Rahmawati, Universitas PGRI Yogyakarta \\ sellyarditya@gmail.com \\ Tri Siwi Nugrahani, Universitas PGRI Yogyakarta \\ trisiwinugrahani26@gmail.com
}

\begin{abstract}
ABSTRAK
Tujuan penelitian ini adalah untuk mengetahui bagaimana mengembangkan pendekatan kreatif inovatif dalam meningkatkan jiwa kewirausahaan serta untuk mengetahuai keefektifan pendekatan tersebut dalam meingkatkan jiwa kewirausahaan. Latar belakang penelitian ini adalah karena pembelajaran pendidikan kewirausahaan yang telah dilaksanakan hanya menekankan pada aspek kognitifnya saja. Selaian itu rendahnya minat mahasiswa dalam mengikuti hibah Program Kreativitas Mahasiswa dan Kompetisi Bisnis Mahasiswa Indonesia juga menjadi salah satu indikasi bahwa jiwa kewirausahaan mahasiswa kurang. Penelitian ini menggunakan metode penelitian $R \& D$ atau penelitian pengembangan yang menggunakan model four $\mathrm{D}$ yaitu define, design, develop dan dessiminate. Teknik pengumpulan data dalam penelitian ini adalah dengan menggunakan angket. Teknik analisis data yang digunakan adalan analisis deskriptif kualitatif dan analisis statistik inferensial dengan menggunakan independent sample t-test. Hasil penelitian ini adalah 1) Pengembangan pendekatan kreatif inovatif untuk meningkatkan jiwa kewirausahaan dilaksanakan dengan four $D$ yaitu define, design, develop dan desseminate; 2) Pendekatan kreatif inovatif sangat efektif untuk meningkatkan jiwa kewirausahaan.
\end{abstract}

Kata Kunci: kreatif, inovatif, jiwa, kewirausahaan

\section{ABSTRACT}

The aim of this study was to find out how to develop innovative, creative approaches in enhancing the entrepreneurial spirit and to find out the effectiveness of this approach in increasing the entrepreneurial spirit. The background of this study is the learning of entrepreneurship education that has been implemented only emphasizes the cognitive aspects. In addition, the low of students interesting in participating in the grant of the Student Creativity Program and the Indonesian Student Business Competition is also one indication that the entrepreneurial spirit of students is lacking. This study used $R \& D$ research methods or development research that used a four-D model that is defined, design, develop and disseminate. The data collection technique in this study was using a questionnaire. The data analysis technique used is qualitative descriptive analysis and inferential statistical analysis using the independent sample t-test. The results of this study are 1) Development of innovative, creative approaches to improve the entrepreneurial spirit carried out with four D, namely define, design, develop and disseminate; 2) Innovative creative approaches are very effective in enhancing the entrepreneurial spirit.

Keywords: creative, innovative, the entrepreneurial spirit 


\section{PENDAHULUAN}

Pengangguran intelektual semakin meningkat di Indonesia. Berdasarkan data Badan Pusat Statistik (BPS) pada bulan Agustus 2017 tingkat pengangguran mencapai 5,50\%. Data pengangguran yang berasal dari lulusan Perguruan Tinggi mencapai tingkat yang lebih tinggi yaitu sebesar 5,18\%. Angka ini akan terus bertambah tiap tahun. Dampak krisis global dan ekspansi kegiatan usaha membuat lulusan Perguruan Tinggi menjadi semakin sulit mendapatkan pekerjaan.

Menurut Hendarman, Direktur Kelembagaan Dikti Depdiknas (Direktorat Jendral Pembelajaran dan Kemahasiswaan, 2015) menyatakan bahwa angka pengangguran semakin tinggi seiring dengan tingginya pendidikan seseorang. Tingginya tingkat pendidikan seseorang berbanding terbalik dengan jiwa kewirausahaannya. Banyak lulusan Perguruan Tinggi hanya berpikir untuk mencari pekerjaan (job seeker) daripada menciptakan lapangan pekerjaan (job creator). Sistem pembelajaran Perguruan Tinggi umumnya memang fokus pada ketepatan lulus dan kecepatan memperoleh pekerjaan, dan memarginalkan kesiapan untuk menciptakan pekerjaan.

Pendidikan kewirausahaan di tingkat perguruan tinggi bertujuan mengubah orientasi mahasiswa sehingga tidak hanya berorientasi untuk mencari pekerjaan. Namun sistem pendidikan yang umumnya masih menggunakan prinsip learning to know, menjadikan pendidikan kewirausahaan sebagai pendidikan yang bersifat teoritis terkait teori-teori berwirausaha. Pendidikan kewirausahaan tersebut tidak dapat menumbuhkan jiwa kewirausahaan lulusan. Padahal negara akan lebih maju kalau jumlah wirausahawannya lebih dari $2 \%$ dari populasi penduduknya. Berdasarkan data dari LIPI pada 2012, jumlah wirausahawan mencapai 1,56\%. Pertambahan jumlah wirausahawan harus terus didorong oleh semua pihak khususnya Perguruan Tinggi. Internalisasi jiwa wirausaha harus diimplementasikan dalam sistem pendidikan tinggi.

Kewirausahaan adalah kegiatan berspekulasi dan mengambil risiko (Kao, 1989). Kewirausahaan dibangun dari kreatifitas dan inovasi dalam mengeksplorasi kesempatan. Pendidikan kewirausahaan di UPY dilaksanakan dalam mata kuliah kewirausahaan dan berbagai mata kuliah lain sebagai hidden curriculum (Suryana, 2006). Namun berdasarkan hasil observasi pelaksanaan perkuliahan kewirausahaan, penanaman jiwa wirausaha masih belum terkarakterisasi ke dalam diri mahasiswa. Padahal pendidikan kewirausahaan sangat mempegaruhi jiwa entrepreneurship seseorang. Hal tersebut terbukti berdasarkan penelitian Syam, Akib, Yunus, \& Hasbiah, (2018) bahwa ada pengaruh positif antara proses pembelajaran kewirausahaan terhadap motivasi wirausaha di Universitas Negeri Makassar. Hal tersebutjuga telihat dari banyaknya alumni UNM yang menjadi wirausaha karena jiwa wirausaha telah dibudayakan dan dikembangkan saat mengikuti 
proses pembelajaran kewirausahaan. Jadi pembelajaran kewirausahaan di perguruan tinggi berkontribusi pada menciptakan jiwa kewirausahaan.

Selain itu berdasarkan penelitian Hien \& Cho (2018), dalam studi ini, hubungan antara pendidikan kewirausahaan dan niat awal yang inovatif diinvestasikan di kalangan mahasiswa di Vietnam utara. Tiga faktor kewirausahaan, (program kurikuler, program ekstrakurikuler dan pendidikan sosial) diadopsi sebagai variabel independen dan dinilai dalam kombinasi dengan tiga faktor (kemampuan kewirausahaan, sikap dan self-efficacy) sebagai faktor mediasi. Hasil dari penelitian tersebut adalah bahwa program kurikuler dan ekstrakurikuler untuk kewirausahaan memiliki pengaruh positif terhadap sikap siswa dan kemampuan kewirausahaan. Dapat disimpulkan bahwa mahasiswa cenderung meningkatkan niat memulai mereka ketika mereka mempelajari kewirausahaan dan percaya diri dalam kemampuan dan self-efficacy mereka. Sikap kewirausahaan juga merupakan faktor keberhasilan. Secara umum penelitian tersebut menyatakan bahwa pelatihan dan pengajaran di universitas dapat mempromosikan kewirausahaan.

Hal tersebut juga didukung oleh hasil penelitian Krabel (2018) banyak universitas mendukung lulusan dalam berwirausaha dengan mendukung kegiatan wirausaha siswa dan staf, menginstal program kewirausahaan dan menciptakan jaringan dengan wirausaha lokal. Menurut survei pascasarjana skala besar, yang dilaksanakan oleh Pusat Internasional untuk Penelitian Pendidikan Tinggi-Kassel, dikombinasikan dengan sistem peringkat orientasi kewirausahaan di antara universitas-universitas Jerman dan data tentang tenaga kerja di dalam wilayah universitas. Analisis empiris menunjukkan bahwa kemungkinan memasuki wirausaha berhubungan positif secara signifikan dengan dukungan dan pengembangan orientasi kewirausahaan dari universitas.

Universitas PGRI Yogyakarta juga telah memiliki kurikulum dengan mata kuliah wajib universitas yaitu pendidikan kewirausahaan. Namun pada mata kuliah pendidikan kewirausahaan dan mata kuliah lain, pembelajaran hanya fokus pada pembelajaran kompetensi mata kuliahnya saja sehingga mahasiswa masih terbatas pada kompetensi pedagogik yang mengutamakan pengetahuan kurang memperhatikan kompetensi afektif dan psikomotornya. Padahal diperlukan jiwa kewirausahaan yang kuat untuk menghadapi persaingan ketat.

Manurut Smile Dzisi (2017) mengungkapkan penggunaan pendekatan pengajaran pasif tradisional dan bertahap pada mata kuliah kewirausahaan dapat mempengaruhi kemampuan siswa secara praktis dalam menerapkan pengetahuan dan keterampilan mereka yang diperoleh melalui pendidikan dan pelatihan. Inovasi yang dilakukan oleh mahasiswa harus terus didorong dan didukung untuk memperkuat jiwa kewirausahaan. Ini akan membantu dalam menghasilkan lulusan yang kompeten dengan keterampilan kerja. Walaupun menurut Dieter Bogenhold and Jarna Heinonen and Elisa Akola (2013) menyatakan bahwa tidak semua pengusaha menghasilkan kekayaan dan penciptaan pekerjaan. Penciptaan pekerjaan dalam kewirausahaan mungkin 
hanya terbatas pada diri mereka saja, keluarga maupun teman. Namun, ini menyiratkan bahwa kontribusi mereka sangat berharga dan dibutuhkan dalam masyarakat.

UPY telah memiliki Unit Pusat Karir yang mengurusi secara administratif serta menyelenggarakan pelatihan-pelatihan terkait kewirausahaan. Namun jumlah mahasiswa UPY yang berminat mengikuti kegiatan Program kreativitas mahasiswa (PKM) dan Kompetisi Bisnis Mahasiswa Indonesia (KBMI) juga sangat sedikit. Hal tersebut karena mahasiswa kesulitan dalam proses menyusun rancangan proposal PKM dan KBMI. Hal ini ditunjukkan dengan rendahnya angka partisipasi mahasiswa dalam menyusun proposal PKM dan KBMI yang yang ditawarkan dari Dikti. Untuk itu penanaman jiwa kewirausahaan di tingkat universitas sangatlah penting.

Usaha untuk mewujudkan itu diperlukan model pembelajaran yang kreatif dan inovatif. Salah satu pendekatan pembelajaran yang berorientasi pada pembentukan jiwa kewirausahaan bertitik tolak pada pemecahan masalah yang diangkat dari realita di sekitar mahasiswa dengan menggunakan pendekatan kreatif - inovatif.

Menurut Suryana (2006) jiwa kewirausahaan terdapat pada jiwa semua orang yang inovatif dan kreatif serta menyukai perubahan, kemajuan dan tantangan. Orang-orang tersebut biasanya adalah birokrat, mahasiswa, dosen, dan masyarakat biasa. Meredith et al (1984) menyatakan bahwa wirausaha adalah orang-orang yang berorientasi kepada prilaku, dan memiliki motivasi yang tinggi serta memiliki kesiapan menghadapi resiko untuk mewujudkan tujuan. Jiwa kewirausahaan merupakan jembatan antara pengetahuan dengan realitas pasar.

Kewirausahaan mengacu pada perilaku yang meliputi pengambilan inisiatif, mengorganisasi dan mengorganisasi kembali mekanisme sosial dan ekonomi untuk mengubah sumber daya dan situasi pada perhitungan praktis dan penerimaan terhadap resiko dan kegagalan. Pembelajaran kewirausahaan diperlukan untuk membentuk nilai atau watak karena dalam pembelajaran kewirausahaan berorientasi kepada tindakan, dan bermotivasi tinggi dalam mengambil resiko.

Pendekatan kreatif dan inovatif ini merupakan pendekatan yang sesuai untuk meningkatkan jiwa kewirausahaan mahasiswa agar lebih kreatif dan inovatif sehingga mahasiswa mampu bersaing dunia kerja dengan mengembangkan wirausaha. Menurut Sutadji (2012), pendekatan kreatifproduktif merupakan pendekatan dengan bentuk model pembelajaran yang mengacu pada prosedur pembelajaran konstruktivisme, dengan memfasilitasi peserta didik membangun sendiri konsep-konsep baru berdasarkan konsep yang telah dimiliki. Menurut Supardan (2015) model konstruktivisme "Siklus Belajar", yang tahapan-tahapannya; (a) diskaveri, yaitu guru mendorong siswa untuk bertanya dan menduga-duga; (b) Pengenalan Konsep; yaitu guru memperkenalkan konsep sesuai dengan bahan kajian yang sedang dikaji; (c) 
Aplikasi Konsep; yaitu guru mengimplementasikan konsep tersebut. Tahapan-tahapan tersebut dapat diulang dalam siklus berikutnya.

Pendekatan kreatif inovatif telah terbukti dapat meningkatkan sikap mahasiswa hal tersebut terlihat dari penelitian Badraningsih Lastariwati (2007) untuk meningkatkan minat dan karakter mandiri mahasiswa. Pendekatan kreatif inovatif terbukti lebih efektif dibandingkan pendekatan lainnya karena dibimbing oleh dosen ketika tahapan implementasi dan refleksi. Berdasarkan latarbelakang tersebut, peneliti ingin mengembangkan pendekatan kreatif inovatif untuk meningkatkan jiwa kewirausahaan mahasiswa.

\section{METODE PENELITIAN}

Penelitian ini menggunakan pendekatan penelitian pengembangan (R\&D). Model pengembangan yang digunakan dalam penelitian ini adalah model pengembangan perangkat Four-D. Model ini terdiri dari 4 tahap pengembangan yaitu define, design, develop, dan disseminate (Sivasailam Thiagarajan, dorothy S Semmel, 1974).

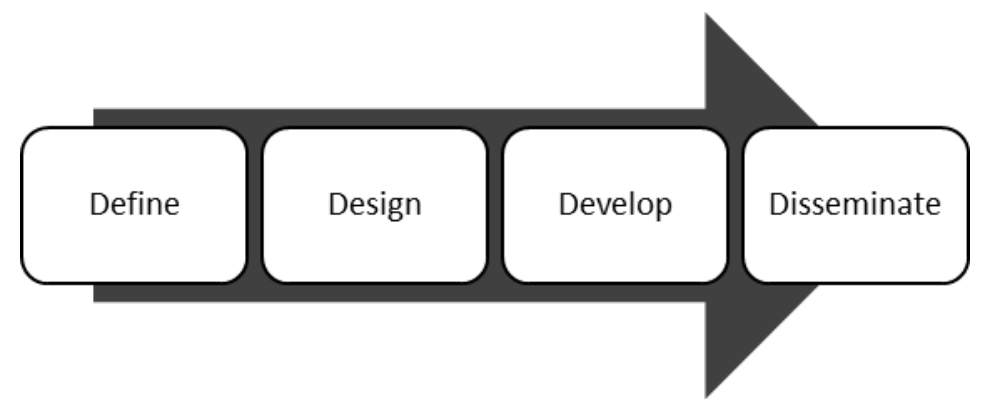

Gambar 1. Tahapan penelitian four D

Tahap define adalah tahap untuk medefinisikan syarat yang diperlukan dalam pembelajaran. Tahap design adalah tahap penyusunan perangkat pembelajaran. Tahap develop yaitu tahap pengembangan produk. Tahapan pengembangan produk ini kemudian diikuti dengan dua langkah selanjutnya yaitu (1) penilaian ahli (expert appraisal) yang diikuti dengan revisi, (2) uji coba pengembangan (developmental testing). Tahap diseminasi yaitu tahap dimana peneliti menyebarkan informasi terkait produk yang dikembangkan. (Sivasailam Thiagarajan, dorothy S Semmel, 1974)

Subyek uji coba dalam penelitian ini adalah mahasiswa UPY yang mendaftar dalam workshop pelatihan kewirausahaan. Penelitian ini dilakukan pada tahun akademik 2018/2019 di Universitas PGRI Yogyakarta. Teknik pengumpulan data dilakukan dengan cara kuisioner dengan instrumen pengumpulan data yaitu angket jiwa kewirausahaan. Sedangkan teknik analisis data menggunakan statistik deskriptif dan statistik inferensial. Analisis statistik deskriptif dilakukan untuk mendapatkan skor data yang diperoleh. Analisis Statistik inferensial yang dilakukan adalah Uji komparatif. Apabila data memiliki distribusi normal dan variansi yang homogen, maka 
dapat dilakukan uji statistik parametrik yaitu uji independet sample t-test. Sedangkan apabila data tidak berdistribusi normal, maka dilakukan uji statistik non parametrik dengan uji mann-whitney u-test.

\section{HASIL PENELITIAN DAN PEMBAHASAN}

\section{Pengembangan Pendekatan Kreatif Inovatif}

Proses pengembangan pendekatan kreatif dan inovatif yang dikembangkan dalam penelitian ini dilaksanakan dengan menggunakan teori 4D (Sivasailam Thiagarajan, dorothy S Semmel, 1974). Teori 4D terdiri dari 4 tahap yaitu define, design, develop dan disseminate.

\section{Define}

Tahap ini terkait terdapat beberapa langkah yaitu font-end analysis, learner analysis, task analysis, concept analysis, specifying instructional objectives. Peneliti melaksanakan langkah-langkah tersebut metode pengumpulan data menggunakan wawancara dan observasi. Font-end analysis merupakan analisis terkait permasalahan dasar yang dihadapi dosen. Berdasarkan hasil analisis analisis ditemukan bahwa akar permasalahan dasar adalah karena model pembelajaran yang konvensional yang hanya berfokus pada aspek kognitif kewirausahaan saja sehingga tidak dapat menggugah jiwa kewirausahaan mahasiswa. Jiwa kewirausahaan harus diajarkan pula secara kreatif dan inovatif.

Learner analysis merupakan identifikasi karakteristik siswa yang relevan dengan design yang dikembangkan. Pada tahap ini ditemukan bahwa mahasiswa memiliki karakter yang pasif namun memiliki pemikiran yang sangat unik sehingga model pembelajaran yang dapat mengaktifkan mahasiswa untuk menemukan ide-ide yang baru harus dikembangkan.

Task analisis yaitu terkait identifikasi tugas yang komprehensif dalam materi pengajaran. Pada tahap ini peneliti mengintegrasikan nilai kewirusahaan dengan pemberian tugas-tugas yang dapat mengaktifkan mahasiswa dan membuka pemikiran mahasiswa untuk mendapatkan ide-ide kewirausahaan yaitu tugas pembuatan proposal kewirausahaan atau KBMI. Setelah mahasiswa menyelesaikan tugas tersebut maka mahasiswa dapat memiliki kompetensi untuk mencari peluang dan melakukan analisis bisnis dan perencanaan praktik inovasi.

Concept analysis yaitu identifikasi konsep utama yang akan diajarkan, mengatur sistematika/hierarki materi dan memecah konsep individu menjadi atribut kritis. Analisis konsep ini juga membantu mengidentifikasi seperangkat contoh-contoh rasional. Pada tahap ini peneliti menemukan bahwa konsep utama yang harus diajarkan adalah bisnis plan dan contoh jenis-jenis industri kreatif. Pembelajaran konsep tersebut dilaksanakan dengan bentuk workshop-workshop yang menggunakan model konstruktivisme "Siklus Belajar" yang dimodifikasi 
Specifying instructional objectives yaitu mengubah hasil analisis tugas dan konsep diatas menjadi tujuan yang dinyatakan secara perilaku. Pada tahap ini menetapkan tujuan pembelajaran ini adalah mengembangkan jiwa wirausaha dengan kompetensi dapat mengimplementasikan ide-ide kewirausahaan dalam bisnis plan berbasis proposal PKM kewirausahaan atau KBMI.

\section{Design}

Pada tahap ini dilakukan constituting criterion referenced adalah tahap menentukan, tes acuan patokan untuk mengukur jiwa wirausaha mahasiswa. Pada tahap ini peneliti memilih angket jiwa kewirausahaan untuk megevaluasi jiwa kewirausaan mahasiswa. Setelah tahap tersebut, dilakukan Media selection yaitu pemilihan media yang sesuai untuk penyajian konten pembelajaran. Proses ini melibatkan pencocokan analisis tugas dan konsep, karakteristik target-trainee, sumber daya produksi, dan rencana diseminasi dengan berbagai atribut media yang berbeda.

Tabel 1. Tahapan sintak pendekatan kreatif inovatif

\begin{tabular}{|c|c|c|c|}
\hline No & Tahapan & Kegiatan guru & Kegiatan siswa \\
\hline \multirow[t]{3}{*}{1} & Diskaveri & $\begin{array}{l}\text { 1. Dosen membagi mahasiswa } \\
\text { menjadi } 11 \text { kelompok, dimana } \\
\text { dalam satu kelompok terdapat } 3 \\
\text { mahasiswa }\end{array}$ & $\begin{array}{l}\text { 1. Siswa berkumpul dengan } \\
\text { kelompoknya masing- } \\
\text { masing }\end{array}$ \\
\hline & & $\begin{array}{l}\text { 2. Dosen mempresentasikan jenis- } \\
\text { jenis usaha kreatif yang terkenal } \\
\text { dan sukses di yogyakarta }\end{array}$ & $\begin{array}{l}\text { 2. Siswa memperhatikan } \\
\text { penjelasan guru }\end{array}$ \\
\hline & & $\begin{array}{l}\text { 3. Dosen meminta Mahasiswa } \\
\text { menganalisis dari berbagai } \\
\text { sumber apa faktor pendukung } \\
\text { yang membuat usaha-usaha } \\
\text { tersebut menjadi terkenal/sukses }\end{array}$ & $\begin{array}{l}\text { 3. Mahasiswa melakukan } \\
\text { analisis pasar terhadap } \\
\text { jenis usaha-usaha } \\
\text { tersebut. }\end{array}$ \\
\hline \multirow[t]{2}{*}{2} & $\begin{array}{l}\text { Pengenalan } \\
\text { Konsep }\end{array}$ & $\begin{array}{l}\text { 1. Dosen mengundang narasumber } \\
\text { untuk menjelaskan faktor } \\
\text { pendukung kesuksesan usaha } \\
\text { kreatifnya yang salah satunya } \\
\text { adalah terkait bussnies plan yang } \\
\text { matang }\end{array}$ & $\begin{array}{l}\text { 1. Mahasiswa } \\
\text { mengkonstruksikan } \\
\text { pemahamannya }\end{array}$ \\
\hline & & $\begin{array}{l}\text { 2. Dosen menjelaskan teori } \\
\text { pembuatan terkait Business plan }\end{array}$ & $\begin{array}{l}\text { 2. Mahasiswa } \\
\text { mengkontruksi } \\
\text { pemahaman yang pernah } \\
\text { dia dapat dengan } \\
\text { penjelasan yang di } \\
\text { dapatkan dari guru }\end{array}$ \\
\hline \multirow[t]{2}{*}{3} & $\begin{array}{l}\text { Aplikasi } \\
\text { Konsep }\end{array}$ & $\begin{array}{l}\text { 1. Dosen meminta mahasiswa } \\
\text { membuat business plan dalam } \\
\text { format proposal PKM } \\
\text { kewirausahaan atau proposal } \\
\text { KBMI }\end{array}$ & $\begin{array}{l}\text { 1. Mahasiswa praktek } \\
\text { membuat business plan } \\
\text { dalam format proposal } \\
\text { PKM kewirausahaan atau } \\
\text { proposal KBMI }\end{array}$ \\
\hline & & $\begin{array}{l}\text { 2. Dosen meminta mahasiswa } \\
\text { merefleksikan rencana bisnis } \\
\text { yang telah dibuat }\end{array}$ & $\begin{array}{l}\text { 2. Mahasiswa merefleksikan } \\
\text { rencana bisnis yang telah } \\
\text { dibuat }\end{array}$ \\
\hline
\end{tabular}


Pemilihan akhir mengidentifikasi media atau kombinasi media yang paling tepat untuk digunakan. Pada tahap ini peneliti memilih media pembelajaran audio visual yaitu melalui film-film kewirausahaan dan melalui presentasi Power Point. Langkah selanjutnya adalah format selection. Pemilihan format yang paling tepat tergantung pada sejumlah factor yang dibahas. Peneliti melakukan pemilihan format sesai dengan standar proses dikti yang disesuaikan dengan sintak model pembelajaran dengan pendekatan kreatif inovatif. Tahap selanjutnya yaitu melakukan Initial design adalah penyajian instruksi penting melalui media yang sesuai dan dalam urutan yang sesuai. Ini juga melibatkan penataan berbagai kegiatan belajar. Pada tahap ini peneliti membuat rencana pembelajaran dengan pendekatan kreatif inovatif, bahan ajar, media pembelajaran serta instrumen penilaian.

Rencana pembelajaran dengan mengembangkan model pendekatan kreatif inovatif dengan model konstruktivisme siklus belajar dalam bentuk workshop mencakup sintak yang telah dijabarkan pada tabel 1. Instrumen penilaian dalam workshop ini adalah lembar tugas, angket jiwa kewirausahaan. Angket jiwa kewirausahaan ini mencakup kisi-kisi pengambilan inisiatif, mengorganisasi dan mengorganisasi kembali mekanisme sosial dan ekonomi untuk mengubah sumber daya dan situasi pada perhitungan praktis dan penerimaan terhadap resiko dan kegagalan.

\section{Develop}

Tahap pengembangan adalah untuk memodifikasi model pembelajaran. Pada tahap pengembangan, umpan balik diterima melalui expert appraisal yaitu teknik untuk mendapatkan saran untuk peningkatan materi. Pada tahap ini, peneliti meminta ahli model pembelajaran dan ahli materi kewirausahaan untuk mengevaluasi model pembelajaran dan materi dari sudut pandang pengajaran dan teknis. Atas dasar umpan balik mereka, model tersebut dimodifikasi untuk membuatnya lebih sesuai, efektif, dapat digunakan, dan berkualitas teknis tinggi.

Sintak dan rencana pembelajaran untuk model pembelajaran ini kemudian divalidasi oleh ahli model pembelajaran yaitu dosen matakuliah dosen mata kuliah model pembelajaran. Hasil penilaian ahli model pembelajaran dapat dilihat pada tabel 2 .

Tabel 2. Hasil Kualitas Model Pembelajaran

\begin{tabular}{ll}
\hline \multicolumn{1}{c}{ Aspek } & Nilai \\
\hline Model merujuk pada teori & 8 \\
kejelasan tujuan pembelajaran & 8 \\
Terdapat metode perbaikan pembelajaran & 8 \\
Terdapat dampak terapan model & 8 \\
Total Skor Penilaian & 40 \\
Interval Penilaian & 80 \\
Kriteria & Baik
\end{tabular}


Berdasarkan penilaian ahli model pembelajaran dari tabel 2. diketahui bahwa model pembelajaran pendekatan kreatif inovatif berbasis model konstruktivisme siklus belajar masuk dalam kriteria baik. Sedangkan penilaian materi kewirausahan dilakukan ahli materi kewirausahaan yaitu dosen mata kuliah kewirausahan dapat dilihat pada tabel 3.

Tabel 3. Kualitas materi

\begin{tabular}{lc}
\multicolumn{1}{c}{ Aspek } & Nilai \\
\hline Kesesuaian materi dengan indikator pembelajaran & 8 \\
Ketepatan materi dengan tujuan pembelajaran & 8 \\
Kelengkapan materi yang disajikan & 7 \\
Keruntutan susunan materi yang disajikan & 8 \\
Kedalaman materi yang disajikan & 7 \\
Kesesuaian contoh yang disajikan dengan materi & 8 \\
Skor Penilaian & 46 \\
Interval & 76,6 \\
Kriteria & Baik \\
\hline
\end{tabular}

Berdasarkan tabel 3. diketahui bahwa materi untuk pendekatan kreatif inovatif berbasis konstruktivisme siklus belajar masuk dalam kriteria baik. Setelah melakukan penilaian ahli materi dan ahli model pembelajaran diketahui bahwa model pembelajaran telah masuk dalam kriteria baik. Setelah tahap tersebut, peneliti melakukan developmental testing melibatkan mencoba materi dengan peserta pelatihan yaitu mahasiswa. Peneliti melakukan pengujian dengan membandingkan jiwa kewirausahaan kelas yang menggunakan model pembelajaran konvensional dengan kelas yang menggunakan model pembelajaran dengan pendekatan kreatif inovatif berbasis konstruktifisme siklus belajar dan melakukan revisi hingga model tersebut bekerja secara konsisten dan efektif. Berdasarkan hasil ujicoba tersebut dapat dilihat pada gambar 2 .

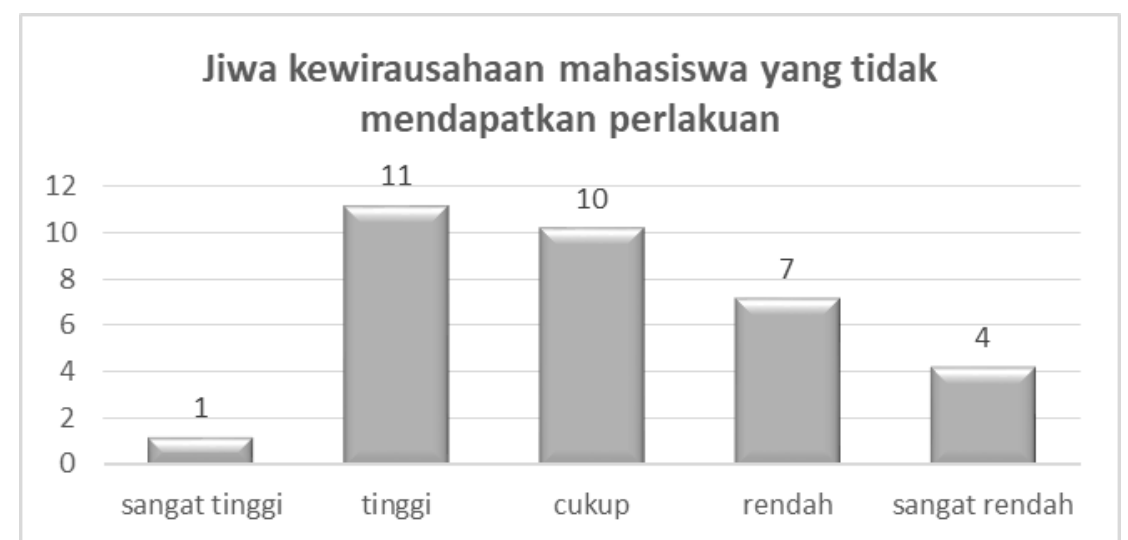

Gambar 2. Jiwa kewirausahaan mahasiswa yang tidak mendapatkan pendekatan kreatif inovatif 
Berdasarkan gambar 2. diketahui bahwa jiwa kewirausahaan mahasiswa yang tidak mengikuti workshop cukup baik namun masih ada 7 mahasiswa yang memiliki jiwa kewirausahaan yang rendah dan 4 mahasiswa dengan kriteria sangat rendah. Sedangkan data jiwa kewirausahaan mahasiswa yang mengikuti workshop juga dapat dilihat dalam gambar diagram batang pada gambar 3.

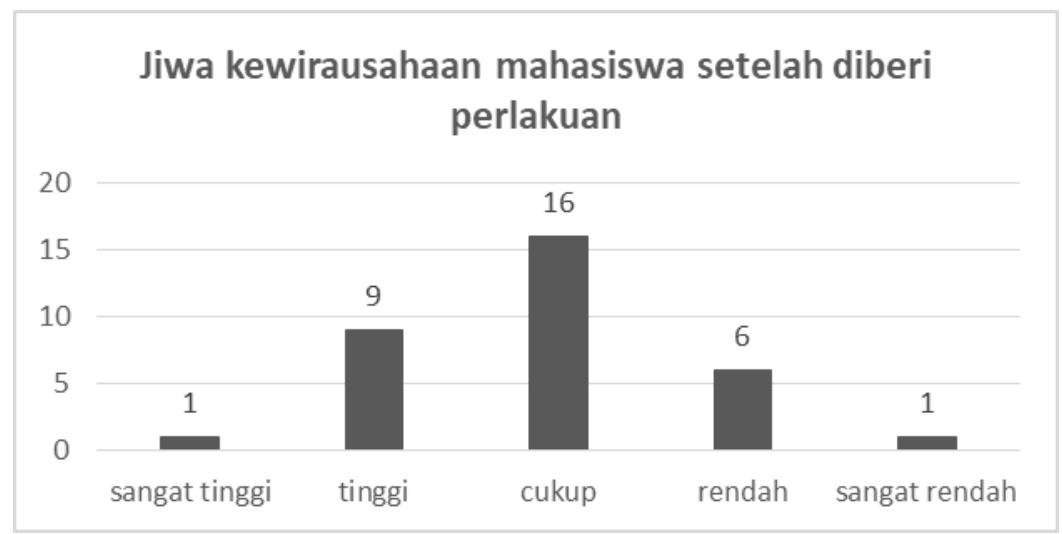

Gambar 3. Jiwa kewirausahaan mahasiswa yang mendapatkan pendekatan kreatif inovatif

Berdasarkan data dari gambar 3. dapat kita lihat bahwa jiwa kewirausahaan mahasiswa setelah mengikuti workshop juga cukup baik, sedangkan yang memiliki jiwa kewirausahaan yang rendah masih terdapat 6 mahasiswa dan sangat rendah hanya 1 mahasiswa. Sedangkan hasil rata-rata tiap aspeknya dapat dilihat pada gambar 4 .

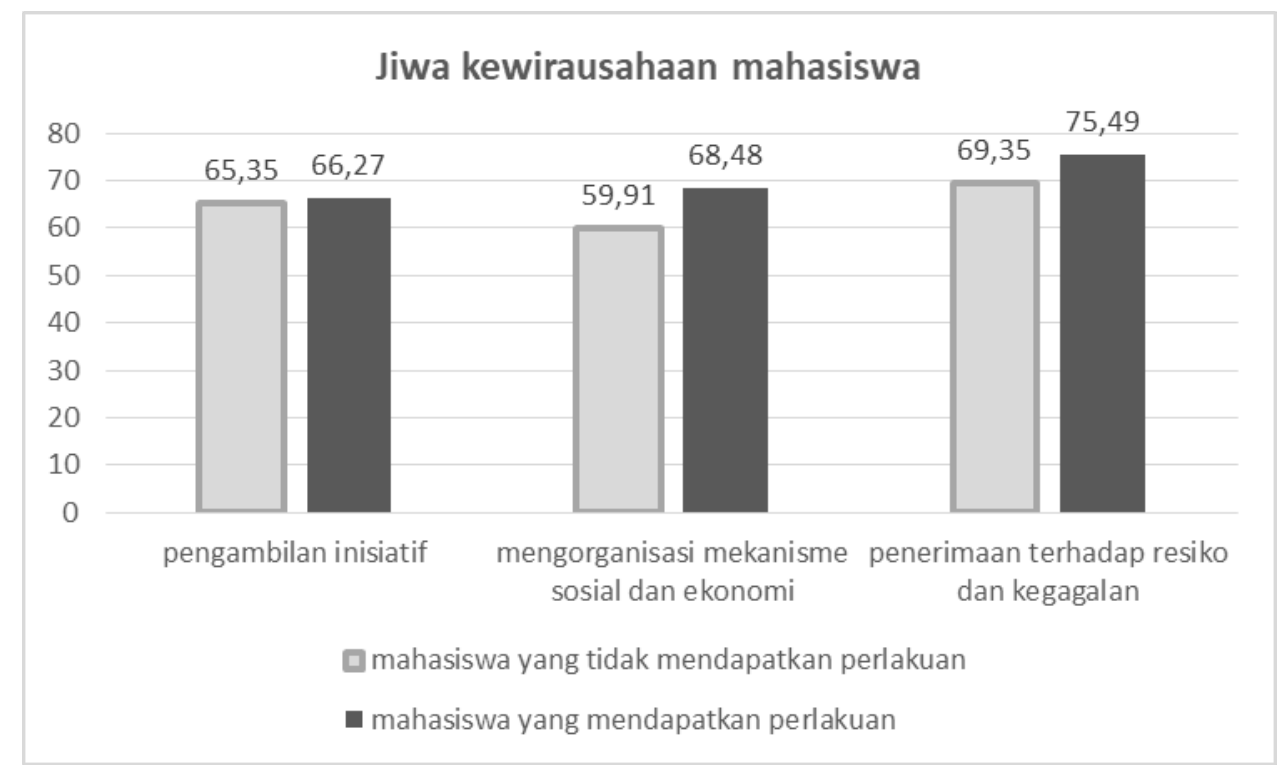

Gambar 4. Jiwa kewirausahaan mahasiswa berdasarkan aspek kewirausahaan

Dari gambar 4. diketahui bahwa nilai aspek pengambilan inisiatif mahasiswa yang tidak mengikuti workshop dan mahasiswa yang mengikuti 
workshop memiliki nilai yang sama yaitu masuk pada kriteria cukup. Pada aspek mengorganisasi mekanisme sosial dan ekonomi, mahasiswa yang tidak mengikuti workshop mendapat nilai yang lebih rendah dari mahasiswa yang mengikuti workshop. Mahasiswa yang tidak mengikuti workshop masuk dalam kriteria rendah sedangkan mahasiswa yang mengikuti workshop masuk dalam kriteria cukup. Pada aspek penerimaan terhadap resiko dan kegagalan, mahasiswa yang tidak mengikuti workshop dan yang mengikuti workshop mendapatkan nilai yang hampir sama yaitu masuk dalam kriteria tinggi. Namun mahasiswa yang tidak mengikuti workshop mendapat nilai 69,35 sedangkan mahasiswa yang mengikuti workshop mendapat nilai 75,49.

Untuk memastikan perbedaan jiwa kewirausahaan mahasiswa yang tidak mengikuti dan yang telah mengikuti workshop, peneliti juga melakukan analisis statistik inferensial dengan melakukan uji hipotesis. Berdasarkan uji prasyarat normalitas dan homogenitas, data jiwa kewirausahaan mahasiswa ini termasuk data yang berdistribusi normal dan homogen. Sehingga peneliti melakukan analisis dengan menggunakan uji independent sample t-test. Berdasarkan uji tersebut terlihat pada tabel 4.

Tabel 4. Hasil independent Sample t-test

\begin{tabular}{cc} 
Sig.2 tailed & 0,009 \\
\hline $\mathrm{t}$ & $-2,681$
\end{tabular}

Berdasarkan data dari tabel 4 diketahui bahwa nilai significansi jiwa kewirausaan mahasiswa yang telah mengikuti workshop dan mahasiswa yang tidak mengikuti workshop adalah 0,009. Nilai tersebut lebih kecil dari 0,05 sehingga $\mathrm{H} 0$ ditolak dan Ha diterima. Jadi dapat disimpulkan bahwa terdapat perbedaan jiwa kewirausahaan antara mahasiswa yang mengikuti workshop dengan pendekatan kreatif inovasif berbasis konstruktivisme siklus belajar dengan yang tidak mengikuti workshop. Berdasarkan tabel diatas diketahui bahwa nilai $\mathrm{t}$ adalah $-2,681$ hal tersebut berarti bahwa kelompok ke 2 (mahasiswa yang mengikuti workshop) yang lebih efektif dibandingkan dengan kelompok 1. Hal tersebut juga terlihat dari hasil rata-rata kedua kelompok pada gambar 5.

Efektifitas pendekatan kreatif inovatif berbasis konstruktivisme siklus belajar juga terlihat dari gambar 5 yaitu nilai rata-rata kelas eksperimen yang lebih tinggi dari kelas kontrol.

Pada tahap develop ini diketahui bahwa terdapat perbedaan jiwa kewirausahaan antara mahasiswa yang mengikuti workshop dengan pendekatan kreatif inovasif berbasis konstruktivisme siklus belajar dengan yang tidak mengikuti workshop. Rata-rata jiwa kewirausahaan mahasiswa yang menggunakan model pendekatan kreatif inovatif adalah 70,27 yang lebih tinggi dari pada kelas yang menggunakan metode konvensional. 


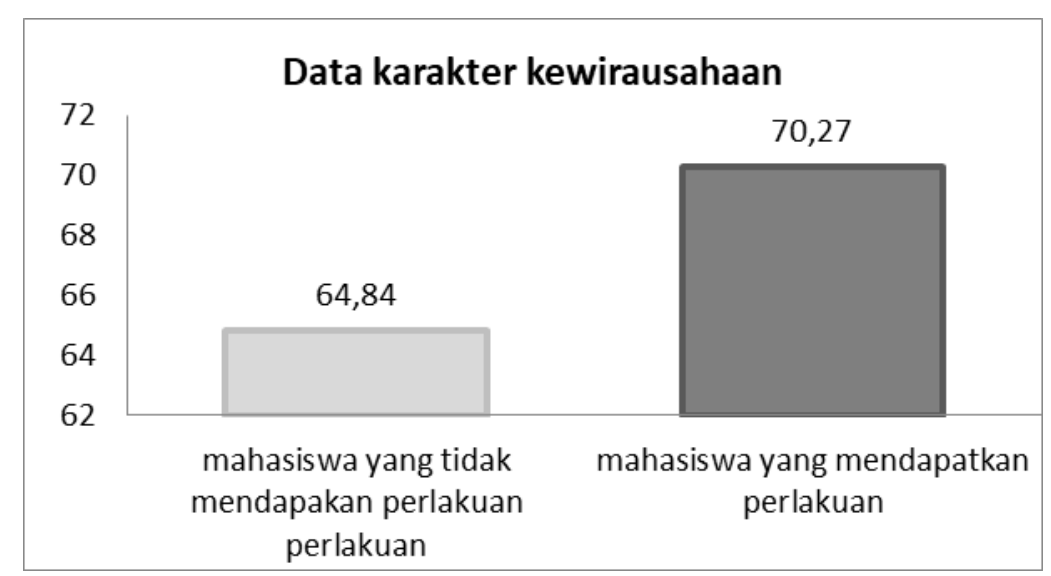

Gambar 5. Rata-rata jiwa kewirausahaan mahasiswa

\section{Disseminate}

Model pembelajaran mencapai tahap produksi akhir ketika pengujian perkembangan menghasilkan hasil yang konsisten dan penilaian ahli menghasilkan komentar positif. Sebelum menyebarkan model pembelajaran dengan pendekatan kreatif inovatif ini, evaluasi dilakukan. Dalam fase pengujian validasinya, model tersebut digunakan dalam kondisi yang dapat ditiru. Materi tersebut juga harus menjalani pemeriksaan profesional untuk mendapatkan pendapat yang objektif tentang kecukupan dan relevansinya. Tahap akhir dari pengemasan akhir, difusi, dan adopsi adalah dengan mendistribusikan model pembelajaran secara luas di antara dosen-dosen matakuliah pendidikan kewirausahaan sehingga mendorong adopsi dan aplikasi model pembelajaran dengan pendekatan kreatif inovatif. Distribusi model pendekatan kreatif inovatif ini dilakukan dalam forum group discussion (FGD) bersama dosen-dosen yang mengampu matakuliah wajib universitas pendidikan kewirausahaan.

\section{Efektifitas Pendekatan Kreatif Inovatif}

Berdasarkan hasil penelitian diatas, diketahui bahwa pendekatan kreatif dengan model pembelajaran konstruktivisme siklus belajar lebih efektif dalam menanamkan jiwa kewirausahaan mahasiswa. Hal tersebut karena model konstruktifisme siklus belajar menuntut mahasiswa aktif mengkonstruksikan pengetahuannya. Model konstruktivistik memastikan mahasiswa mengkonstruksikan makna yang didapat dalam pembelajaran. Dengan mengkonstruksikan makna, mahasiswa dapat memahami konsep materi tersebut (Muijs, Daniel, \& Renold, 2009). Jadi ketika mahasiswa mengkontruksikan pengetahuannya tentang insdustri kreatif, mahasiswa akan mendapatkan makna pentingnya menciptakan instrustri kreatif bagi diri mereka dan masyarakat. Melalui makna tersebut maka jiwa kewirausahaan untuk aspek mengambil inisiatif menjadi meningkat.

Selain itu dengan model konstruktivisme siklus belajar, guru memberi contoh jenis industri kreatif yang sukses dan mengundang salah satu wirausahawan yang sukses mengeluti bisnis kreatif sehingga hal tersebut 
meningkatkan kemauan mahasiswa dalam mengeksplorasi gagasan-gagasan terkait industri kreatif. Hal tersebut sesuai dengan pendapat Paris, Scott G. Byrnes, James P. Paris (2001) yang menyatakan bahwa Siswa dapat aktif mengkonstruksi makna bila Guru mengkonstruksikan kegiatan-kegiatan yang dapat membuat siswa dapat mengeksplorasi gagasan. Pembelajaran kontruktivistik memiliki arti belajar dengan mendalam sehingga siswa dapat mengkonstruksikan keseluruhan informasi yang telah didapatkan dengan mengeksplorasi dan melihat ulang informasi-informasi yang telah dimiliki.

Senada dengan hal tersebut, Ernst (1989) menyatakan bahwa mengajar adalah mengembangkan siswa untuk mengeksplorasi dan merefleksi pengalamannya. Model pembelajaran ini dapat membuat siswa lebih memahami materi. Hal tersebut sesuai dengan hasil penelitian ini yang dapat dilihat dari aspek organisasi mekanisme sosial dan ekonomi, dimana siswa yang mendapatkan workshop dapat memiliki jiwa mengorganisasikan mekanisme yang cukup, sedangkan yang tidak mengikuti workshop hanya memiliki jiwa mengorganisasikan mekanisme yang rendah. Hal tersebut karena mahasiswa yang mengikuti workshop dituntut mengeksplorasi kemampuan dan kreativitasnya dalam menjadi wirausaha dengan merencanakan usahanya dalam praktek penyusunan bussnies plan. Mahasiswa yang mengikuti workshop dapat memiliki pemahaman yang lebih dalam mengorganisasikan bussnies plan dibanding yang tidak mengikuti workshop. Refleksi dalam proses pembelajaran konstruktivisme ini juga dapat meningkatkan jiwa menerima resiko.

\section{SIMPULAN}

Berdasarkan penelitian di atas ditemukan bahwa pengembangan pendekatan kreatif inovatif untuk meningkatkan jiwa kewirausahaan yang dilaksanakan dengan four $D$ terbukti efektif untuk meningkatkan jiwa kewirausahaan. Berdasarkan temuan tersebut dapat disimpulkan dalam penelitian model pembelajaran dengan pendekatan kreatif inovatif memiliki manfaat sebagai berikut.

1. Aktif mengkonstruksikan pengetahuan dan makna yang didapat dalam pembelajaran

2. Membuat siswa dapat mengeksplorasi gagasan

3. Membantu siswa untuk dapat merefleksikan pengalamannya.

Berdasarkan penelitian tersebut maka peneliti memberikan saran terhadap dosen-dosen mata kuliah pendidikan kewirausahaan agar menerapkan model pembelajaran dengan pendekatan kreatif inovatif sehingga mahasiswa tidak hanya mendapatkan aspek kognitif saja, namun juga keterampilan dan sikap wirausaha.

\section{DAFTAR RUJUKAN}

Badraningsih Lastariwati. (2007). Sampul Implementasi model pembelajaran kreatif produktif untuk meningkatkan kualitas mata kuliah praktek seni 
penyajian makanan pada program studi teknik boga.pdf. Universitas Negeri Yogyakarta.

Dieter B̈ogenhold and Jarna Heinonen and Elisa Akola. (2013). Entrepreneurship and Independent Professionals: Why do Professionals not meet with Stereotypes of Entrepreneurship? 4(39922), 0-29. Retrieved from https://pdfs.semanticscholar.org/05fa/c5b9abfbdb8b3d1491fcde398c0715 b6f546.pdf

Direktorat Jendral Pembelajaran dan Kemahasiswaan. (2015). Pedoman Program Mahasiswa Wirausaha. Yogyakarta: Direktorat Jendral Pembelajaran dan kemahasiswaan.

Ernst. (1989). Cognition, Construction of Knowledge, and Teaching. Synthese, $\quad 80(1), \quad$ 121-140. Retrieved from https://www.univie.ac.at/constructivism/EvG/papers/118.pdf

Hien, D. T. T., \& Cho, S. E. (2018). Relationship between entrepreneurship education and innovative start-up intentions among university students. International Journal of Entrepreneurship, 22(3), 1-16. Retrieved from https://www.abacademies.org/articles/Relationship-betweenentrepreneurship-education-and-innovative-start-up-intentions-amonguniversity-students-1939-4675-22-3-175.pdf

Kao, J. J. (1989). sampul Entrepeneurship creativity dan organization. New Jersey: Prentice Hall Englewood Cliffs.

Krabel, S. (2018). Are entrepreneurs made on campus? The impact of entrepreneurial universities and graduates' human capital on graduates' occupational choice. Journal of International Entrepreneurship, 16(4), 456-485.

Meredith, G. G., Asparsayogi, A., Nelson, R. E., \& Nick, P. A. (1984). Kewirausahaan Teori dan Praktek (Vol. 52). Retrieved from http://search.proquest.com/docview/1651837258?accountid=14548

Muijs, Daniel, \& Renold, F. (2009). Effectiveness and disadvantage in education. Can a focus on effectiveness aid equity in education? In educational and poverty in affluent Countries (pp. 101-112). Routledge.

Paris, Scott G. Byrnes, James P. Paris, A. H. (2001). Self-regulated learning and academic achievement. In Constructing theories, identities, and actions of self-regulated learners (pp. 253-287). New York: SpringerVerlag.

Sivasailam Thiagarajan, dorothy S Semmel, M. I. S. (1974). Instructional Development for Training Teachers of Exceptional Children: A Sourcebook. Minneapolis. 
Smile Dzisi, F. O. (2017). sampul entrepeneurship education and training in higher educational institutions in ghana. Journal of International Entrepreneurship, 15(4), 436-452.

Supardan, D. (2015). Manusia Kekerasan Multikultur dan Transformasi Pendidikan. Bandung: Rizqi.

Suryana. (2006). Kewirausahaan: Kiat dan proses menuju sukses. Jakarta: Salemba Empat.

Sutadji, E. (2012). Penerapan Pembelajaran Kreatif Dan Inovatif Melalui Dengan Kegiatan Lesson Study Untuk Meningkatkan Pemahaman Mahasiswa Dalam Metrologi Industri. Jurnal Teknik Mesin, 20(1). Retrieved from https://media.neliti.com/media/publications/140929-IDpenerapan-pembelajaran-kreatif-dan-inova.pdf

Syam, A., Akib, H., Yunus, M., \& Hasbiah, S. (2018). Determinants of Entrepreneurship Motivation for Students at Educational Institution and Education Personnel in Indonesia. Journal of Entrepreneurship Education, 21(2), 1-12. Retrieved from https://www.abacademies.org/articles/Determinants-of-entrepreneurshipmotivation-for-students-1528-2651-21-2-167.pdf 
